\title{
Give a fish or teach to fish? Empowerment as a practice of social innovation in a civil society organization
}

\author{
THAís TELES FiRMINo ${ }^{1}$ \\ André Gustavo Carvalho Machado ${ }^{1}$ \\ ${ }^{1}$ Universidade Federal da Paraíba / Departamento de Administração, JoÃo Pessoa - PB, Brazil
}

\begin{abstract}
This article aims to analyze empowerment as a practice of social innovation in a civil society organization (CSO) working with vulnerable children and adolescents in the Northeast of Brazil. The study adopted an ethnometodological approach, using interviews with the organization's staff, children and adolescents that participate or participated in the project, and their families. In addition, the study used participant observation, photos, videos, and document analysis. The results show that besides the individuals empowerment, the participants of the project became multipliers of the acquired knowledge, contributing to the development of other people in their networks. The social innovation practice analyzed has changed over time based on the action and demands of the children and adolescents involved, following their personal development process. Also, the practice is improved based on the CSO's planning and work of mapping community needs. This article contributes to delineate an integrative theoretical conception, helping to investigate how the practice develops over time and is legitimized in the context, evidencing its founding elements and means of materialization.
\end{abstract}

Keywords: Social innovation. Practice. Empowerment. CSO. Social vulnerability.

\section{Dar o peixe ou ensinar a pescar? O empoderamento como prática de inovação social em uma organização da} sociedade civil

\section{Resumo}

O objetivo geral deste artigo foi analisar o empoderamento como prática de inovação social em uma organização da sociedade civil (OSC) nordestina. Assim sendo, selecionamos como exemplo de prática de inovação social o empoderamento de crianças e adolescentes vulneráveis socialmente. Para tanto, lançamos mão de entrevistas com funcionários da OSC, alunos, ex-alunos e familiares, observações participantes, fotos, vídeos e documentos, baseando-nos nos direcionamentos etnometodológicos. Neste contexto, foi expressivo descobrir que, além do desenvolvimento do poder pessoal, os alunos matriculados nas atividades da OSC tornavam-se multiplicadores dos conhecimentos adquiridos, contribuindo para o crescimento das pessoas de sua convivência. Esta prática se modifica ao longo do tempo pelas próprias ações das crianças e adolescentes, acompanhando seu processo de desenvolvimento pessoal, como também pelo mapeamento de necessidades das comunidades e planejamento das atividades que a OSC realiza. Ademais, este artigo contribui de diversas maneiras, em especial no que se refere ao delineamento de uma concepção teórica integrativa e à investigação de como a prática se desenvolve e se legitima em um dado contexto, evidenciando seus gatilhos e meios de materialização.

Palavras-chave: Inovação social. Prática. Empoderamento. OSC. Vulnerabilidade social.

\section{¿Dar un pescado o enseñar a pescar? El empoderamientocomo práctica de innovación social en una organización de la sociedad civil}

\section{Resumen}

El objetivo general de este artículo fue analizar el empoderamiento como práctica de innovación social en una organización de la sociedad civil (OSC) del nordeste de Brasil. Así pues, seleccionamos como ejemplo de práctica de innovación social el empoderamiento de niños y adolescentes vulnerables socialmente. Para ello, recurrimos a entrevistas con empleados de la OSC, alumnos, exalumnos y familiares, observaciones participantes, fotos, videos y documentos, basándonos en las directrices etnometodológicas. En este contexto, fue significativo descubrir que, además del desarrollo del poder personal, los alumnos matriculados en las actividades de la OSC se convertían en multiplicadores de los conocimientos adquiridos, contribuyendo al crecimiento de las personas con las que convivían. Esta práctica se modifica a lo largo del tiempo a partir de las propias acciones de los niños y adolescentes, acompañando su proceso de desarrollo personal, así como a partir del mapeo de necesidades de las comunidades y planificación de las actividades que la OSC realiza. Además, este artículo contribuye de diversas maneras, en especial en lo que se refiere al delineamiento de una concepción teórica integrativa y a la investigación de cómo la práctica se desarrolla y legitima en un contexto dado, evidenciando sus desencadenantes y medios de materialización.

Palabras clave: Innovación social. Práctica; Empoderamiento. OSC. Vulnerabilidad social. 


\section{INTRODUCTION}

Brazil occupies the 79th position in the world ranking of human development (UNPD, 2016) and remains among countries with the most inequality in Latin America (IBGE, 2015), presenting challenges in several areas, such as health, education, housing, safety, ethnicity, gender, income distribution, and work. In this context, we perceive distortions that progress over time and cause the perpetuation of a condition of exclusion and social vulnerability, which can lead to discrimination and the isolation of individuals (COSTA and MARGUTI, 2015). This scenario is reflected in the most recent studies, positioning the country in an average level of social vulnerability (COSTA and MARGUTI, 2015). Contrary to the national index, as highlighted by the latter authors, the North and Northeast regions have the highest concentrations of municipalities with very high vulnerability levels, further evidencing inequalities.

In this scenario, the situation of children and adolescents deserves attention because current and future experiences of deprivation impact their human development and transition into adulthood (COSTA and MARGUTI, 2015). In addition, children and adolescents represent the expectation of changing these conditions in the search for a more just country. However, despite the promulgation of the Estatuto da Criança e do Adolescente (Statute of Children and Adolescents - ECA) in 1990, its fundamentals still need to be understood and practiced in Brazilian municipalities. As an example, there were more than 182,000 complaints of violations of children and adolescents' rights (psychological violence, physical violence, sexual violence, negligence, among others) in 2014 (FUNDAÇÃO ABRINQ, 2016). In an attempt to modify this reality, among other actions, the Federal Government has invested in partnerships with civil society organizations (CSOs) to strengthen the action of the public sphere in face of local needs.

From an academic perspective, a broad field of studies and practice of social innovation (SI) emerges to minimize these inequalities and initiatives. In this context, Van der Have and Rubalcaba (2016) identified that publications on this subject have shown steady growth since 2003. The explanation for this growing interest seems to be in the increasing number of social, economic and environmental problems as well as in the changes in society and culture (MURRAY, MULGAN and CAULIERGRICE, 2008; CAJAIBA-SANTANA, 2014). As a consequence of these demands in different scenarios, $\mathrm{SI}$ is interdisciplinary, encompassing approaches from several areas of knowledge that act from different angles.

We also found a set of gaps caused by the need for greater conceptual clarity, the fragility of theoretical perspectives, and the lack of comprehension of the social innovation process (HOWALDT and SCHWARZ, 2010; VAN DER HAVE and RUBALCABA, 2016; SILVEIRA and ZILBER, 2017), as well as the incipience of studies on the subject in Brazil (AGOSTINI, VIEIRA, TONDOLO et al., 2017). Additionally, the literature emphasizes that understanding the topic requires new theoretical bases to explore the links between innovation and social change (HOWALDT, DOMANSKI and KALETKA, 2016; AGOSTINI, VIEIRA, TONDOLO et al., 2017; SILVEIRA and ZILBER, 2017).

In light of this, we adopted the view of SI as a practice, while recognizing its process as a phenomenon built by the daily interactions between those involved. Therefore, in this article, Sls are "[...] new social practices created from collective, intentional, and goal-oriented actions aimed at prompting social change through the reconfiguration of how goals are accomplished" (CAJAIBA-SANTANA, 2014, p. 44). Social practices, in turn, are organized human activities (groups of actions) (SCHATZKI, 2001). Each activity that constitutes the practice involves intelligible sayings (basic actions that say something about something) and actions (basic actions performed by people with their bodies) in a given context (SCHATZKI, 2001). According to this reasoning, $\mathrm{Sl}$ aims to change collective behavior and manifests itself through new practices arising from a collaborative and continuous process.

We outlined our research problem considering the relevance of studies of this nature to regions with clear social problems and challenges (IWAMOTO and CANÇADO, 2016), the role of CSOs together with other organizations in minimizing this scenario, and the misunderstanding of how each actor contributes to the development of innovations (AGOSTINI, VIEIRA, TONDOLO et al., 2017). Starting from the principle of ethnomethodological indifference (BISPO and GODOY, 2014), i.e., not defining an a priori practice, empowerment emerged after immersion in the field, in an emergent manner, without a prior intention. With this, we were guided by the following question: how does the development of empowerment as a practice of SI occur in an organization of a Brazilian northeastern civil society that acts in the inclusion of children and adolescents from disadvantaged communities? 
Empowerment, in turn, is a process of seeking autonomy and self-determination, in which a sense of personal power develops; this does not exclude the possibility of the individual being helped in this trajectory by professionals or external agents (KLEBA and WENDAUSEN, 2009; GONZALEZ-MENA, 2015). Therefore, the main objective of this article is to analyze empowerment as a practice of $\mathrm{SI}$ in an organization of Brazilian northeastern civil society.

The results of this research contribute to advance the theme of $\mathrm{SI}$ by adopting a new theoretical basis to understand innovation (HOWALDT, DOMANSKI and KALETKA, 2016; AGOSTINI, VIEIRA, TONDOLO et al., 2017) and by longitudinally analyzing innovation and its effects (AYOB, TEASDALE and FAGAN, 2016) by comparing a previous situation with a later situation in a given context (MAURER and SILVA, 2015). In addition, from the methodological point of view, this study confirms the potential for the adoption of Garfinkel's ethnomethodology as a method to be used in organizational studies (ADAMOGLU DE OLIVEIRA and MONTENEGRO, 2012).

After this introduction, we outline the theoretical orientations that underlie our understanding of the development of SI practices. Next, we describe the methodological procedures. Thereafter, we discuss the results and present the conclusions.

\section{THEORETICAL ORIENTATION}

Given the growing increase in social needs, studies on social innovation have received more attention, leading to advances beyond academic boundaries (SILVA and BITENCOURT, 2016). In addition to the significant conceptual contributions that have been made by university research centers, efforts have been made to develop public policies, practice and research on $\mathrm{SI}$, such as The Young Foundation, the Nesta and the European Commission in the United Kingdom and the OECD at the global level (POL and VILLE, 2009; SILVA and BITENCOURT, 2016).

Through a literature review, we realized that studies on SI are marked by a myriad of works from different perspectives, which causes conceptual ambiguity and inevitable theoretical delimitations (CAJAIBA-SANTANA, 2014; PHILLIPS, LEE, JAMES et al., 2015; VAN DER HAVE and RUBALCABA, 2016). We identified that a first step towards orientation within the topic is to reflect on the meanings of the terms "innovation" and "social," which constitute the concept. Innovation lies in the perception of novelty for those involved in the process; its context; or even in the form of application of the initiative; for example, access to the Internet is not an innovation for a large businessperson but it can be one for an indigenous community in isolation. Regarding the social context, some authors (MURRAY, MULGAN and CAULIER-GRICE, 2008; PHILLS, DEIGLMEIER and MILLER, 2008) understand that the term encompasses broad and global social challenges, such as problems arising from climate change.

Other authors (MOULAERT, MARTINELLI, SWYNGEDOUW et al. 2005; MONTGOMERY, 2016) are concerned with more specific issues of groups from a local development perspective, such as social exclusion (MAURER and SILVA, 2015; VAN DER HAVE and RUBALCABA, 2016), and this is the most widespread perception. There is also a line of studies (CAJAIBA-SANTANA, 2014; HOWALDT, KOPP and SCHWARZ, 2015) that treats SIs as practice, and for this reason, "social" arises through collective and intentional action towards changes in any strata of society, not necessarily to meet the demands of marginalized groups or global challenging situations. Because we are guided by the perspective of SI as a practice, we understand that the unit of analysis should be the practice itself, which means an empirical focus on processes of change and social recognition of the sets of activities. At the same time, we identified in the studies a concern with how SIs can meet the demands of minorities and, above all, empower them.

With this emphasis on local development, there are more results-oriented approaches (MULGAN, TUCKER, ALI et al., 2007; POL and VILLE, 2009), focusing on alternatives and solutions that generate social change, that is, the forms that SI assumes, its results. According to Moulaert, Martinelli, Swyngedouw et al. (2005) and Murray, Mulgan and Caulier-Grice (2008), it has several forms, including products, services, models, methodologies and forms of governance. There are also more processoriented approaches (MOULAERT, MARTINELLI, SWYNGEDOUW et al. 2005; MONTGOMERY, 2016), which aim to understand social change by focusing on the transformation of practices that generate exclusion and social vulnerability.

In this context, some authors (MOULAERT, MARTINELLI, SWYNGEDOUW et al. 2005; ANDRÉ and ABREU, 2006; MONTGOMERY, 2016) argue that results-oriented approaches are palliative means of responding to social demands because innovations in this context often place subjects in a consumer condition, leaving them dependent on external 
agents. According to these authors, the objective should be to empower the subjects and, therefore, integrate the target groups in the process, increasing their participation (IWAMOTO and CANÇADO, 2016; MONTGOMERY, 2016). With this reasoning, process-oriented approaches are concerned with the empowering potential of innovations, which, in turn, provide greater durability to the results.

In $\mathrm{SI}$, empowerment is understood as greater access to resources that enable the satisfaction of human needs, together with greater social and political participation (MOULAERT, MARTINELLI, SWYNGEDOUW et al. 2005; ANDRÉ and ABREU, 2006; MONTGOMERY, 2016). Given the case studied, we chose to understand empowerment as a process of seeking autonomy and self-determination, in which a sense of personal power develops, which does not exclude the possibility of the individual being helped by professionals or external agents in this trajectory (KLEBA and WENDAUSEN, 2009; GONZALEZ-MENA, 2015). We observed that when dealing with innovations to confront social inequalities, they can be understood analogously to the dilemma of solving poverty: give a man a fish or teach him how to fish? With this expression, we seek to show the usefulness of the innovations studied by results-oriented approaches (give a man a fish) by transforming practices that perpetuate the situation of exclusion and social vulnerability (teach a man how to fish).

For example, people who are in a precarious housing situation and starving themselves can be greatly helped by a social enterprise that enables adequate food and housing (give a man a fish). Having their basic needs met, this same group can participate in training aimed at their insertion in the labor market (teach a man how to fish). This implies thinking about $\mathrm{SI}$ as a continuous process, so that over time it may have different forms according to the context, producing results that are more palliative and/or dependent on external agents and, at other times, that are long-lasting through the development of subjects' sense of personal power. The latter are more difficult to disseminate because they involve personal transformations loaded with meaning and significance that are very specific to the groups.

As with all practices, innovations are largely tacit and symbolic (BISPO, 2013). From this point of view, analyzing the process of SI involves the "[...] understanding of how the way of organizing of social actors are produced and reproduced" (BISPO, 2013, p. 18). Therefore, the identification of the triggers that lead to its emergence and subsequent development is part of the mapping of the previous situation, according to Maurer and Silva (2015), so that the researcher discovers the dysfunctions in the current practices from the perspective of the actors involved in the dynamics of change in practices. At the same time, the understanding (PHILLIPS, LEE, JAMES et al., 2015; CORREIA, OLIVEIRA and GOMEZ, 2016) that collective learning paves the way for the development of innovations is well understood.

It therefore becomes logical that the emergence of new practices occurs through interactions between social actors, who, impregnated by extremely tacit and symbolic elements, reconfigure the established practices (BISPO, 2013; CORREIA, OLIVEIRA and GOMEZ, 2016). Howaldt, Kopp and Schwarz (2015) argue that this change occurs with the repetition of daily routines that are modified subtly over time until the establishment of the new practice. Thus, we emphasize the importance of valuing the context (HOWALDT and SCHWARZ, 2010; CAJAIBA-SANTANA, 2014) and understanding the meaning and significance shared by a group to obtain greater clarity in the analysis of the change dynamics of practices.

Organizations can play different roles in the development of SIs (CORREIA, OLIVEIRA and GOMEZ, 2016). According to Lyon (2012), there may be vertical relationships, in which a given participant acts by virtue of his or her influence and power over the economic support of what he or she proposed, as well as horizontal relationships, in which there is sharing of knowledge and tools, so that the actors are perceived in a more equitable manner. In this regard, Chalmers (2012) highlights the importance of cultivating a collaborative network in which the partners act together, establishing integrated actions.

Resembling the perspective of open innovation, the exchanges between internal and external environments are more fruitful in the development of social innovations (CHALMERS, 2012; CORREIA, OLIVEIRA and GOMEZ, 2016; SILVA and BITENCOURT, 2016). Moreover, the practice of $S I$ is only successful when socially accepted, i.e., legitimized in the context in question. Given this, the continuity of actions as a result of the receptivity to change of those involved is what consolidates the new practice (HOWALDT, KOPP and SCHWARZ, 2015; MAURER and SILVA, 2015). In this process, the social actors themselves may undergo transformations regarding attitudes, behaviors and perceptions (CORREIA, OLIVEIRA and GOMEZ, 2016). For this reason, the investigation of the activities performed and of the interactions between the actors is a necessary condition for understanding the change dynamics of the practices. 


\section{METHODOLOGY}

Based on the assumption that reality is socially constructed and that the context of the research needs to be considered, Garfinkel's ethnomethodology was adopted as a research method. This approach highlights the sharing of meanings between people in their daily practices, in addition to allowing the study of the ways of organizing those involved in the process of $\mathrm{SI}$ through their own perspective (ADAMOGLU DE OLIVEIRA and MONTENEGRO, 2012; BISPO and GODOY, 2014).

To perform the research, we first conducted a literature review using the Scopus and Scielo databases, due to their relevance and interdisciplinarity, in addition to the inclusion of publications by Brazilian authors. Studies of research organizations and centers were also considered as suggested by Tranfield, Denyer and Smart (2003). A selection criterion was adopted considering only articles from peer-reviewed journals that discussed concepts or models of analysis, management or measurement of SI. By excluding articles that did not meet these criteria, the sample consisted of 44 publications.

Once we defined our theoretical perspective on the topic, we sought to select a case in which (1) there was a local development context whose social problems and challenges were clear; (2) there was more than one actor participating in the process of $\mathrm{Sl}$; and (3) the interactions between these actors intended reconfigurations in the way social objectives are achieved.

Based on the criteria mentioned above, we selected a CSO that has been working since 1985 with the mission of contributing to the realization of human rights, especially children and adolescents in socially vulnerable conditions, with comprehensive education actions, community and institutional articulation and intervention in the spaces of public policies in their state, from a sustainable development perspective.

Among its activities, the promotion of pedagogical workshops for children and adolescents, campaigns of social mobilization and participation and intervention in the spaces for discussion, the formulation and control of public policies for children and adolescents (councils, forums and networks) stand out. Over the years, more than 3,500 children and adolescents have been seen, and annually, more than 170 of them are educated in health, sexuality and citizenship. This was also possible due to the construction of a strong network of partners that enable and support their actions.

To identify the SI to be researched, we practiced ethnomethodological indifference, that is, we inserted ourselves in the field without pre-established definitions of what should be studied (BISPO and GODOY, 2014). Thus, we decided to research empowerment as an example of SI practice, understanding that it brings significant changes to the lives of students and contributes to strengthening the image of the CSO in society. To ensure that the selected practice was an $\mathrm{SI}$, we confirmed that empowerment was perceived as new by children and adolescents, fostered social change and started from collective and intentional actions (CAJAIBA-SANTANA, 2014). When analyzing a previous situation and a later situation in the studied context (HOWALDT, KOPP and SCHWARZ, 2015; MAURER and SILVA, 2015), we realized that the practice was responsible for positive impacts, based on the results documented by the CSO itself and on the perceptions of the benefited individuals.

Given this, having selected the new practice generated aiming for social change (CAJAIBA-SANTANA, 2014; HOWALDT, KOPP and SCHWARZ, 2015), we could observe (1) which actors were involved in the development of this practice, composing the social innovation network and, therefore, the research context (BISPO, 2013; SILVA and BITENCOURT, 2016; AGOSTINI, VIEIRA, TONDOLO et al., 2017) and (2) the context change by the analysis of a previous situation and a later one (HOWALDT, KOPP and SCHWARZ, 2015; MAURER and SILVA, 2015), constituting a longitudinal perspective, which, in turn, favored the understanding of innovations in their historical-cultural context (AYOB, TEASDALE and FAGAN, 2016).

Data were collected between May and November 2017, and participant observations, unstructured interviews, photos, analysis of documents and audio and video recordings were adopted. The results of the daily interactions with members of the CSO in meetings, events and workshops were recorded in a notebook. Among the analyzed documents, we highlight strategic plans, goal plans, statutes, fundraising plans, organizational charts, reports of active projects, and spreadsheets for monitoring educators and students. 
The photos and recordings were useful for constant consultation of the moments in which the students introduced themselves or expressed themselves in events or activities during the workshops, helping to recall the manifestation of the practice of SI identified. The interviews were conducted with administrative and pedagogical coordinators, educators, social workers, students and ex-students. The number of subjects surveyed depended on both the number of organizations involved and data saturation, with 18 interviews conducted.

Data analysis occurred in an interpretive manner aiming at understanding the shared meanings between individuals, so that the key, from an ethnomethodological perspective, was to be sure that the meanings attributed to the interpretations represented the reality lived in the studied context (TEN HAVE, 2004). For this purpose, we used the five key concepts of Garfinkel's ethnomethodology described in Bispo and Godoy (2014) as guidance for ascertaining the characteristics associated with each key concept (Box 1), as these include the central characteristics of this approach.

\section{Box 1}

Analysis and Interpretation of Ethnomethodological Data

\begin{tabular}{|c|c|c|}
\hline Concept & $\begin{array}{c}\text { Theoretical Description } \\
\text { of the Concept }\end{array}$ & $\begin{array}{l}\text { Question for Analytical and } \\
\text { Interpretive Orientation }\end{array}$ \\
\hline $\begin{array}{c}\text { Practice / } \\
\text { Accomplishment }\end{array}$ & $\begin{array}{l}\text { This indicates the experience and practice } \\
\text { of the members of a group in their } \\
\text { everyday context, i.e., it is necessary to } \\
\text { share about daily life and the context } \\
\text { so that it is possible to understand the } \\
\text { practices of the group. }\end{array}$ & $\begin{array}{l}\text { Do the activities identified represent } \\
\text { the everyday life of the researched } \\
\text { organization/group and are they recognized } \\
\text { by their members as their own and } \\
\text { characteristics of the organization/group to } \\
\text { which they belong? }\end{array}$ \\
\hline Indexicality & $\begin{array}{l}\text { This refers to all the circumstances that } \\
\text { a word carries in a situation. This term } \\
\text { is adopted from linguistics and denotes } \\
\text { that at the same time that a word has a } \\
\text { somewhat "generic" meaning, this same } \\
\text { word has distinct meanings in particular } \\
\text { situations. Thus, their understanding, in } \\
\text { some cases, requires that people seek } \\
\text { additional information that goes beyond } \\
\text { the mere generic understanding of the } \\
\text { word. This is the language in use. }\end{array}$ & $\begin{array}{c}\text { Does the set of activities identified have } \\
\text { a language specific to the researched } \\
\text { organization/group in which all members } \\
\text { share it and the meaning(s) it represents in } \\
\text { the daily life of that organization/group? Is } \\
\text { it possible to identify jargon and/or words } \\
\text { of their own? }\end{array}$ \\
\hline Reflexivity & $\begin{array}{l}\text { This is related to the "effects" of the } \\
\text { practices of a group; it is a process in which } \\
\text { an action occurs and, at the same time, } \\
\text { produces a reaction on its creators. }\end{array}$ & $\begin{array}{c}\text { Does the set of identified activities create, } \\
\text { over time, in the organization/group } \\
\text { conditions of perpetuation or modification } \\
\text { or even generate new activities that are } \\
\text { recognized by the members as a result of } \\
\text { their daily lives? }\end{array}$ \\
\hline Accountability & $\begin{array}{l}\text { This is how the study group describes } \\
\text { the practical activities from the reference } \\
\text { of meaning and significance that the } \\
\text { group itself has. It can be considered a } \\
\text { "justification" of the group for a particular } \\
\text { activity and conduct. }\end{array}$ & $\begin{array}{l}\text { Is it possible to identify in the statements } \\
\text { and actions of the members of the } \\
\text { organization/group common justification to } \\
\text { guide the reason why the set of activities } \\
\text { is performed that way and rather than } \\
\text { another way? }\end{array}$ \\
\hline $\begin{array}{c}\text { Notion of } \\
\text { membership }\end{array}$ & $\begin{array}{c}\text { The member is the one that shares the } \\
\text { language of a group, inducing a condition } \\
\text { of "belonging" to and in the group and not } \\
\text { just of "being" in the group. }\end{array}$ & $\begin{array}{l}\text { Does the set of mapped activities allow } \\
\text { the researcher to clearly identify who the } \\
\text { individuals are who effectively belong to } \\
\text { the organization/group and are not just } \\
\text { in it? Indexicality and accountability are } \\
\text { fundamental for this recognition. }\end{array}$ \\
\hline
\end{tabular}

Source: Bispo and Godoy (2014). 
In addition, aiming at methodological rigor, we value the triangulation of data (through the various data collection techniques used), the clear, rich and detailed description of the methodological procedures, and the reflexivity and openness to evidence that stimulate new ways of thinking about the theme (through ethnomethodological indifference and perceptions of reality as socially constructed) (PAIVA JÚNIOR, LEÃO and MELLO, 2011).

\section{DISCUSSION OF THE RESULTS}

This section is divided into three subsections. In the first subsection, we discuss the context, the triggers that lead to social change and the impact of CSO actions on children and adolescents cared for. The second subsection presents the activities that make up the practice of SI. The last subsection describes the actors involved.

\section{Context, triggers and impacts}

The studied CSO is located in the North zone of the capital of a northeastern state of Brazil, in a neighborhood with the highest concentration of individuals from economically disadvantaged strata and high levels of exclusion, characterizing a situation of high social vulnerability and stigmas strengthened by the media (see Figure 1). During walks with members of the CSO through the neighborhood, observations and informal conversations, we observed how this reality occurs in the lives of the families who live in these locations, especially children and adolescents enrolled in the CSO. For example, it is not uncommon for students to be neighbors of drug traffickers and hitmen or even have parents, siblings or relatives involved with illicit substances or in gang disputes.

Some students are even children of drug lords, prisoners and killers. In turn, it is also not difficult to find fearful children and adolescents who do not walk on certain streets because they belong to criminal factions that are rivals to those existing in their own community. Through frequent conversations with educators and support staff and participating in meetings at the CSO, we learned that many children and adolescents attend activities while hungry and dirty. They also informed us that not having food to eat and clothes to wear, as well as money to reverse this situation, is not uncommon, which confirms the reality observed during the walks.

Figure 1

\section{Community Living Conditions}

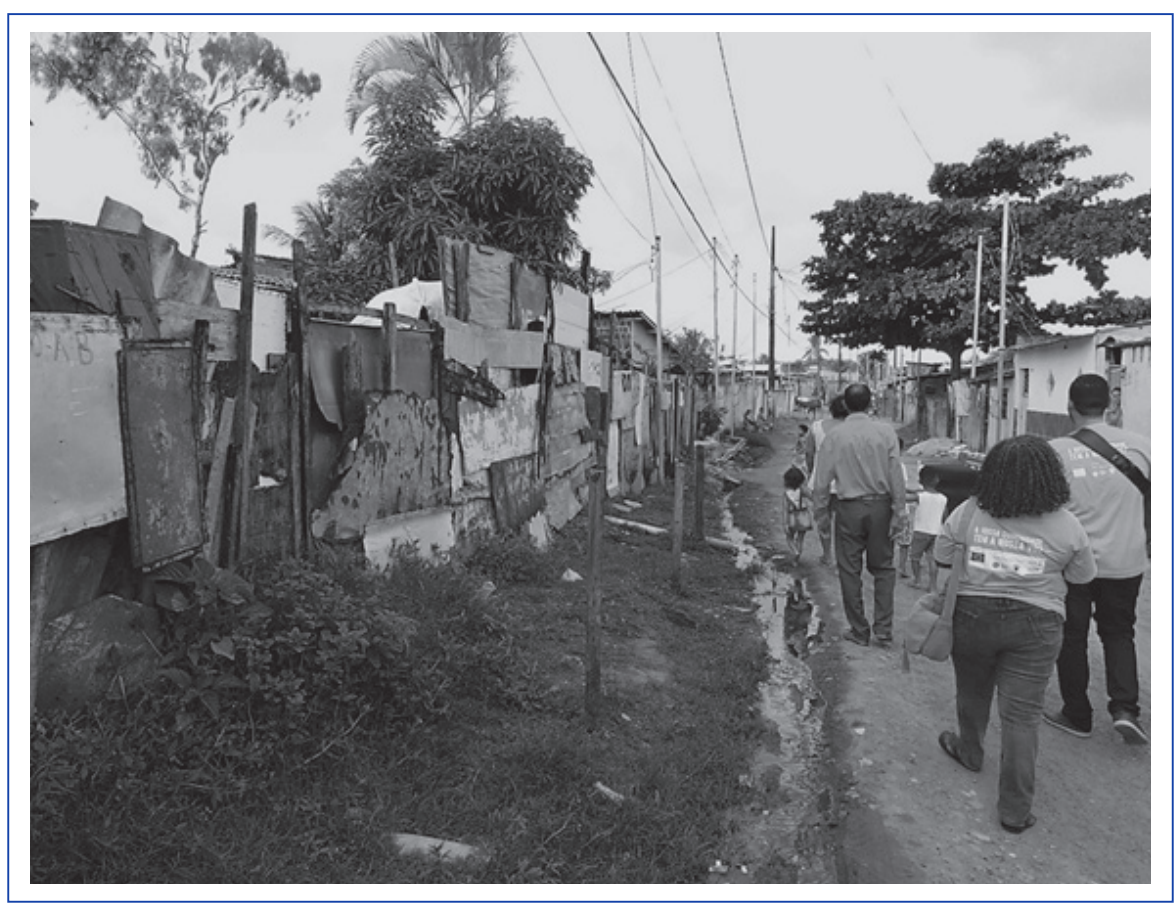

Source: CSO Archive (2018). 
Another issue is the low level of education of heads of household, which also hinders access to jobs and can impact the development of children and adolescents. For example, one of the mothers revealed that she suffered sexual violence and assaulted her children because she lacked direction. However, she said that after enrolling them in the CSO and attending the vocational workshops offered to her and family reunions, she learned how she could be a more caring, thoughtful mother and educate her children without the need for violence. One of the educators told us that in the face of the rejection and abandonment suffered by children and adolescents, the inclusion in drug trafficking as a recruiter (children that address potential clients for sale) was a tempting alternative that welcomed them and promised them financial gains.

In this context, as highlighted by Murray, Mulgan and Caulier-Grice (2008) and Cajaiba-Santana (2014), Sls are favorable initiatives to minimize the negative effects caused by social vulnerability. This is because the growing number of social, economic and environmental problems drives the need to develop new ways of addressing them and/or solving them, aiming at social change by reconfiguring how goals are achieved. We observed, therefore, that the triggers that indicated the need for change were violence and poverty, drug trafficking and the stigma associated with the neighborhood. Therefore, we identified that the practice of empowerment as an SI emerges due to the very situation of social vulnerability in which children and adolescents are immersed. In other words, because of the difficulties and barriers associated with social exclusion, corroborating Howaldt, Kopp and Schwarz (2015), empowerment emerges as an alternative to soften and/or reverse these inequalities.

Thus, the studied CSO appears as a space for community living, being recognized in the neighborhood by the activities undertaken. Its actions are in accordance with the perception of the European Commission (2013) that empowerment through education can be a means of responding to social exclusion. Over the past 32 years, more than ten thousand children, adolescents and youth up to the age of 24 years have participated in the activities offered by the CSO, which contributes to their physical, mental and social development as well as to the mobilization of improvements in the community. Examples of the success of CSO actions are the reduction in cases of violations of rights, the greater inclusion of young people in the labor market and their participation in cultural and artistic presentations, in addition to access to extension courses or extracurricular activities associated with the potential identified in the workshops promoted by the CSO.

Many former students, their families and former CSO employees explained to us how the people who have access to the activities are able to envision other possibilities and means of life that go against what configures the status quo of communities in situations of vulnerability. They can dream and feel capable of achieving these dreams, not yielding to the drug trafficking invitations or the hopelessness that social exclusion produces, for example. Furthermore, some adolescents reported that their way of seeing the world and making decisions is constantly refined because of the knowledge they access through the activities provided by the CSO. These testimonies are also corroborated by ex-students who, in turn, are already experiencing the opportunities they once dreamed.

In addition, in the document analysis, we had access to a study conducted by the CSO with one of its partners that sought to assess the long-term direct impact of their care activities on the lives of children and adolescents in the years 2002 to 2012, called the "Impact Study." We highlight that there is a disparity in the level of education among children and adolescents who attend the CSO and those who do not. In the communities served, which are marked by high social vulnerability, those who participated in workshops had a higher education level. Thus, many ex-students are able to complete university, technical and secondary education, while incomplete elementary education is common among people in these neighborhoods.

Moreover, the effects of SI extend beyond the level of personal autonomy because these people also become multipliers of acquired knowledge. This occurs because, with discussions about monthly topics, they acquire information that can help them not only to protect themselves and their rights but also to help friends and their own family. For example, one of the students said that after having learned and talked about bullying and its consequences in CSO workshops, she felt she was able to teach and be comfortable with teaching her friends when they were disrespectful. In addition, it was also noted in the "Impact Study" (internal document) that the learning extends to the family. In the following subsections, we describe the activities and actors that enabled these achievements. 


\section{Activities that make up the practice of SI}

We understand that the initiatives undertaken by the CSO contribute to the development of SIs. In view of this, we found that the innovations provided by the CSO are aligned with a more process-oriented perspective because they seek to transform the practices that cause social inequalities and, thus, teach a man how to fish. We found that the workshops promoted by the CSO are the primary means for the development of empowerment by children and adolescents. In this sense, it is important to highlight that the workshops are the direct care actions for children and adolescents, aiming at citizen training through cultural, pedagogical and sports activities. Among the different workshops already offered by the CSO are visual arts, dance, singing, yoga, storytelling, drama, youth protagonism, soccer, flute, wind instruments, and music. Individuals in each workshop participate in classes with varied workloads that include both the development in a specific workshop technique and the discussion of the so-called cross-cutting themes, for example, child labor, sexuality, health and hygiene. It is also important to note that students can participate in more than one workshop.

The students are strongly encouraged to grow either in subjective aspects, such as overcoming shyness or search for a professional vocation, or technical aspects, such as the evolution of musical instruments or dance and visual arts. Once they are required to progress, the educators must provide the coordinators with monthly pedagogical reports containing the content addressed, their objectives, planned activities, necessary materials and the results achieved. Such reports allow the monitoring of strategic objectives and subsidize the actions of the CSO, in addition to other reports that are sent to funders as feedback of their investments in social projects, which is what they call "home dynamics." In addition to being reported, the results are perceived by the community and society throughout the year in promoted events, with the participation of children and adolescents.

Annually, the CSO also makes a diagnosis in which the latent problems of the neighborhood and the uneasiness of children and adolescents are mapped. Based on the results, the cross-cutting themes to be discussed in the workshops are established in the annual planning. Thus, if an educator discovers that there is a case of domestic violence occurring with some of his/ her students, for example, in addition to referring this situation to the psychosocial sector (the CSO sector responsible for the monitoring of children, adolescents and their families), he/she can discuss the topic in his/her workshop. In an interview, one teenager explained that discussing these topics helped her to "open her mind" and that, by understanding her rights, she felt more able to express herself to protect her rights, conquering her space.

Based on this, we realize that children and adolescents feel increasingly comfortable communicating their needs through surveys but also throughout the workshops, working as cocreators and even modeling the actions of the CSO, which is in line with Iwamoto and Cançado (2016) and Montgomery (2016).

In the arts workshop, for example, one of the teenagers said that she felt very lonely and her mother was not attentive. With this report, the educator referred her situation to the psychosocial sector and began to encourage her to enroll in more workshops as well as to have a greater participation in group activities. In the dance workshop of a given year, the focus of the classes was classical ballet because it was the style that the students most wanted to learn, and once the educator was informed about this, the request was deemed feasible and was realized. We understand, then, that changes in practice occur according to CSO resources and through communication and mapping of the participants and the neighborhood's needs together with the analysis of feasibility by the CSO. Additionally, the availability of financial and personnel resources are limiting aspects for the development of certain planned activities.

In a conversation with the CSO educators and coordinators, we were told how much observing children and adolescents during the workshops was important because in addition to directing how the educator will act in the classroom, it helps detect the signs of rights violations. When a student, for example, begins to demonstrate aggressive behavior, unlike usual, the educator becomes attentive to verify what is happening so he can take the necessary steps. In turn, we recognize that the work of educators can be refined, enhancing the effects of the practice by reflecting more about their attitudes and behaviors, which sometimes clash with the philosophical position of the CSO.

Because of greater student participation, students become less dependent on the actions of external agents and have a sense of strengthened personal power because the changes develop them as human beings, which makes SI more lasting. Therefore, as highlighted by Correia, Oliveira and Gomez (2016), the continuous interaction between educator and student also leads to empowerment and consequent changes in student attitude, behavior and perception. Notably, children and adolescents have natural dependence; however, here we address empowerment as a process of seeking 
autonomy by discovering potential rather than independence associated with adulthood (financial, emotional and mental). Thus, empowerment is mainly associated with increased self-confidence and self-perception by a rights-holder who has opportunities and the ability to achieve them.

Thus, it is important to highlight how empowerment is exercised differently by each student. While there are some children and adolescents who have significant emotional or physical difficulties that compromise their full and healthy participation in the workshops, there are others who feel very self-confident and demonstrate relevant personal and technical development. Thus, these aspects are perceived by educators during classes, and this continuous observation allows them to understand the development of their students and record it in their reports or make the necessary referrals as well as guide the planning and execution of their workshops.

According to the above, the more empowered students are able to dedicate themselves to the workshops and advances in learning techniques and in understanding and discussing cross-cutting themes. The educators unanimously reported several times that they respect the limitations of each student and that they understand that the learning time is not the same for everyone. On several occasions we observed the educators spending more time with students who had greater difficulty or encouraging those with more advanced knowledge to help others. It is common, for example, in dance workshops that the "bambinas" - a term used by the educator to call the students to class - who master the techniques to assist their classmates in learning the choreographic movements.

Given this, we understand that the attitudes, behaviors and actions of children and adolescents in their daily lives are a means of materializing the empowerment practice. Thus, it is safe to say that this practice takes forms that are more intangible, which are made possible through participatory spaces favored by adults in the workshops offered by the CSO, events and meetings that children and adolescents are invited to participate. Because it involves a set of actions and attitudes that are characteristic of a group, the results become more difficult to disseminate. As Bispo (2013) asserts, practices are largely tacit and symbolic, corroborating several authors (HOWALDT and SCHWARZ, 2010; CAJAIBA-SANTANA, 2014) with regard to the dependent aspect of the context of SIs. In the subsection below, we present other actors that also contribute to the development of the practice.

\section{Actors}

Innovations are developed through the collaboration of several actors that together constitute a network of SI, according to Tanimoto (2012), Phillips, Lee, James et al. (2015) and Silva and Bitencourt (2016). For this reason, it was necessary to identify which of the CSO partners acted in the development of the empowerment practice, and those who somehow supported the direct care actions undertaken in the neighborhood were the analysis approach. For that purpose, during our visits, we talked with employees to understand the organizations mentioned at the meetings, their roles in CSO activities, and how their work process operated. In addition, we also had access to the active project reports and organizational charts of partners, which helped us identify the actors related to the practice.

Thus, the actors involved in the process that constitute the SI network are CSO, neighborhood schools, children and adolescents enrolled in the workshops, the San Zeno Foundation, Itaú Social, the United Nations Educational, Scientific and Cultural Organization (UNESCO), the Rede de Proteção à Criança e ao Adolescente (Network for the Child and Adolescent Protection) of the neighborhood, the Rede de Proteção Estadual (State Protection Network), and the Conselho Consultivo da Criança e Adolescente (Advisory Council for the Child and Adolescent) of the studied municipality. The practice of SI, in accordance with Howaldt, Kopp and Schwarz (2015) and Maurer and Silva (2015), is consolidated by the continuity of actions and collective learning arising from the interactions between these actors. These actors have participated in a more or less active way in encouraging the empowerment of children and adolescents, i.e., with greater or lesser frequency of physical or virtual involvement to develop activities for this purpose. These relationships can be seen in Figure 2 below. 
Figure 2

Participation of the Social Actors

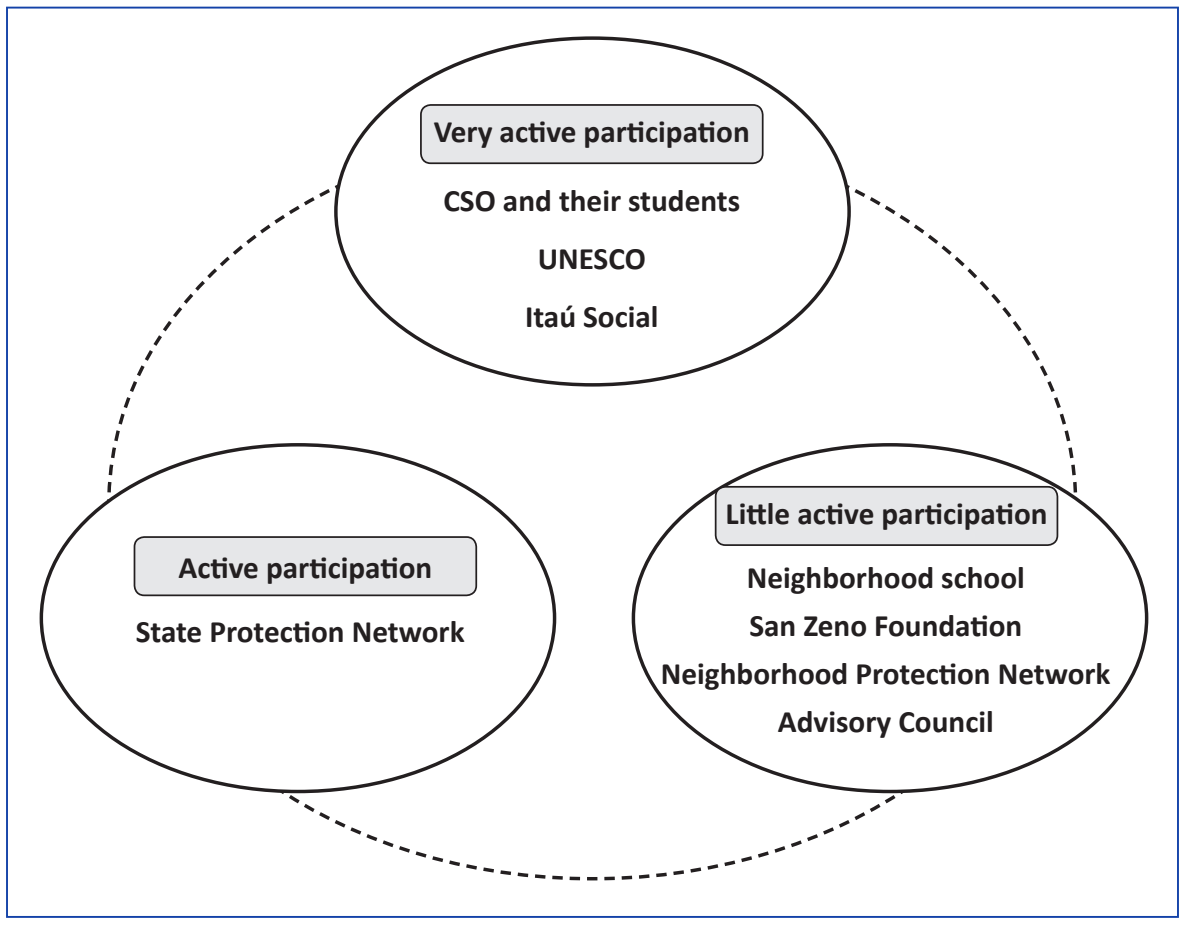

Source: Elaborated by the authors (2018).

We justify that the CSO and their students have very active participation due to their direct and continuous involvement in the workshops. The same is true for the partners Itaú Social and UNESCO because they financially subsidize all the direct care actions performed daily by the CSO and, thus, monitor the actions undertaken to a greater extent. The San Zeno Foundation funds only one of the workshops; therefore, we classified it as little active participation. The local Child and Adolescent Protection Network and the Advisory Council of the municipality possess little active participation in the development of empowerment: they promote monthly discussions between socially vulnerable children and adolescents and adults that can help to change this reality.

The same occurs with the State Protection Network, but this network also provides much support for the partnership with the San Zeno Foundation, which leads us to consider its participation as active. Schools in the neighborhood have little active participation: they contribute annually with the completion of a document called a "school map." In it, the schools report the school situation (performance and frequency in the classes) of the CSO students who study there. Finally, it is understood, in line with Lyon (2012), that the relationships between these actors are horizontal and that the sharing of knowledge and tools is predominant, constituting a collaborative network (CHALMERS, 2012).

\section{CONCLUSION}

The results of this study contribute to the advancement of knowledge on the theme of $\mathrm{SI}$ in several different ways. First, this study attempts to bring greater conceptual clarity and robustness to the theoretical perspective through the understanding of SI as practice, according to the gap pointed out by Howaldt, Domanski and Kaletka (2016) and Van der Have and Rubalcaba (2016). Second, this study expands the incipient Brazilian studies on the subject, as suggested by Agostini, Vieira, Tondolo et al. (2017), and it is performed in a locus with clear social problems and challenges, according to the research opportunity suggested by Iwamoto and Cançado (2016). Third, the investigation of how each actor acts to develop innovations sheds light on the process of $\mathrm{SI}$, contributing to the understanding of the dynamics of change in practice and its legitimization in the 
studied context, according to gaps identified by Grimm, Fox, Baines et al. (2013), Howaldt, Kopp and Schwarz (2015), Agostini, Vieira, Tondolo et al. (2017) and Silveira and Zilber (2017).

In addition, the results are also useful to the development of the field of studies because they longitudinally analyze the innovations and their effects by comparing a previous situation and a later one in a given context, according to research gaps indicated by Maurer and Silva (2015) and Ayob, Teasdale and Fagan (2016). In addition, this study contributes by showing how people become increasingly empowered, following research suggested by Iwamoto and Cançado (2016).

From a methodological point of view, the contribution of this article lies in the fact that it is based on Garfinkel's ethnology, which allows the understanding of the dynamics of change in the practice in a more interpretative perspective. In addition, no previous studies were found that used this approach in the empirical research of SI practices.

From a practical point of view, the research findings provide insights to members of the CSO and to the other participants of the SI network by presenting an overview of its status quo, providing support for problem solving and strategic and operational decisions. They also stimulate the diffusion of SI practices in other domains because successful innovations, according to Phillips, Lee, James et al. (2015), are useful to legislators to produce sustained results that are appropriate and relevant to organizations and society. Therefore, this article may be useful for the creation of public policies or even for aligning with public institutions, encouraging the strengthening of a partnership between sectors, as Phillips, Lee, James et al. (2015) and Pelka and Terstriep highlight (2016).

Some concerns about the subject persist and can be developed in future studies. For example, how are Sls developed in a more favored stratum of society? How does legitimacy of practice occur in a context in which there is little or no active participation of the target group in the process? What are the main differences between the same SI practice that is widespread in other contexts? How do the interactions of the SI network occur when considering the non-human elements of the practice? 


\section{REFERENCES}

ADAMOGLU DE OLIVEIRA, S. A.; MONTENEGRO, L. M. Etnometodologia: desvelando a alquimia da vivência cotidiana. Cadernos EBAPE.BR, Rio de Janeiro, v. 10, n. 1, p. 129-145, 2012.

AGOSTINI, M. et al. An overview on social innovation research: guiding future studies. Brazilian Business Review, v. 14, n. 4, p. 385-402, 2017.

ANDRÉ, I.; ABREU, A. Dimensões e espaços da inovação social. Revista portuguesa de geografia, Finisterra, v. 41, n. 81, p. 121-141, 2006.

AYOB, N.; TEASDALE, S.; FAGAN, K. How Social Innovation 'Came to Be': tracing the Evolution of a Contested Concept. Journal of Social Policy, v. 45, n. 4, p. 635-653, 2016.

BISPO, M. Estudos Baseados em Prática: Conceitos, História e Perspectivas. Revista Interdisciplinar de Gestão Social, v. 2, n. 1, p. 13-33, 2013.

BISPO, M. S.; GODOY, A. S. Etnometodologia: uma Proposta para Pesquisa em Estudos Organizacionais. Revista de Administração da UNIMEP, v. 12, n. 2, p. 108-135, 2014

CAJAIBA-SANTANA, G. Social innovation: moving the field forward. A conceptual framework. Technological Forecasting and Social Change, v. 82, p. 42-51, 2014

CHALMERS, D. Social innovation: an exploration of the barriers faced by innovating organizations in the social economy. Local Economy, v. 28, n. 1, p. 17-34, 2012.

CORREIA, S. E. N.; OLIVEIRA, V.; GOMEZ, C. R. P. Dimensions of social innovation and the roles of organizational actor: the proposition of a framework. RAM - Revista de Administração Mackenzie, v. 17, n. 6, p. $102-133,2016$

COSTA, M; A.; MARGUTI, B. O. (Eds.). Atlas da vulnerabilidade social nos municípios brasileiros. Brasília: IPEA, 2015.

EUROPEAN COMMISION. Social innovation research in the European Union: approaches, findings and future directions. Policy Review. Luxembourg: Publications Office of the European Union, 2013.

FUNDAÇÃO ABRINQ. Cenário da Infância e Adolescência no Brasil 2016. São Paulo: Coktail Gráfica e Editora, 2016. Available at: <https:// goo.gl/MV8fWy>. Accessed on: Aug. 02, 2017.

GONZALEZ-MENA, J. Fundamentos da educação infantil: ensinando crianças em uma sociedade diversificada. 6. ed. Porto Alegre: AMGH, 2015

GRIMM, R. et al. Social innovation, an answer to contemporary societal challenges? Locating the concept in theory and practice. Innovation: the European Journal of Social Science Research, v. 26, n. 4 , p. $436-455,2013$

HOWALDT, J.; DOMANSKI, D.; KALETKA, C. Social Innovation: towards a new innovation paradigm. RAM, Revista de Administração Mackenzie, v. 17, n. 6, p. 20-44, 2016.

HOWALDT, J.; KOPP, R.; SCHWARZ, M. Social Innovation as Drivers of Social Change - Exploring Tarde's Contribution to Social Innovation Theory Building. In: NICHOLLS, A.; SIMON, J.; GABRIEL, M. (Orgs.). New Frontiers in Social Innovation Research. New York: Palgrave Macmillan, 2015. p. 29-51.

HOWALDT, J.; SCHWARZ, M. Social innovation: concepts, research fields and international trends. Dortmund: Sozialforschungsstelle Dortmund, 2010.
INSTITUTO BRASILEIRO DE GEOGRAFIA E ESTATÍSTICA - IBGE. Síntese de Indicadores Sociais: uma análise das condições de vida da população brasileira: 2015. Rio de Janeiro: IBGE, 2015.

IWAMOTO, H. M.; CANÇADO, A. C. Inovação Social e Emancipação: possíveis convergências. In: ENCONTRO NACIONAL DA ASSOCIAÇÃO NACIONAL DE PÓS-GRADUAÇÃO E PESQUISA EM ADMINISTRAÇÃO, 40., 2016, Costa do Sauípe, Anais... Costa do Sauípe: ANPAD, 2016.

KLEBA, M. E.; WENDAUSEN, A. Empoderamento: processo de fortalecimento dos sujeitos nos espaços de participação social e democratização política. Saúde e Sociedade, v. 18, n. 4, p. 733743,2009

LYON, F. Social Innovation, Co-operation, and Competition: Interorganizational Relations for Social Enterprises in the Delivery of Public Services. In: NICHOLLS, A.; MURDOCK, A (Eds.). Social Innovation: Blurring Boundaries to Reconfigure Markets. New York: Palgrave Macmillan, 2012. p. 139-161.

MAURER, A. M.; SILVA; T. N. Como as Inovações Sociais criam e sustentam suas Práticas? Integrando Entendimentos de Inovação Social e Teoria de Práticas. In: ENCONTRO NACIONAL DA ASSOCIAÇÃO NACIONAL DE PÓS-GRADUAÇÃO E PESQUISA EM ADMINISTRAÇÃO, 39., 2015, Belo Horizonte. Anais... Belo Horizonte: ANPAD, 2015.

MONTGOMERY, T. Are Social Innovation Paradigms Incommensurable? Voluntas: International Journal of Voluntary and Nonprofit Organizations, v. 27, n. 4, p. 1979-2000, 2016.

MOULAERT, F. et al. Towards Alternative Model(s) of Local Innovation. Urban Studies, v. 42, n. 11, p. 1969-1990, 2005

MULGAN, G. et al. Social Innovation: what it is, why it matters and how it can be accelerated. London: The Basingstoke Press, 2007.

MURRAY, R.; MULGAN, G.; CAULIER-GRICE, J. How to Innovate: the tools for social innovation - circulated for comment. The Young Foundation Resources, 2008. Available at: <https://youngfoundation. org/wp-content/uploads/2012/10/How-to-innovate-the-tools-forsocial-innovation.pdf>. Accessed on: Nov. 10, 2016.

PAIVA JÚNIOR, F. G.; LEÃO, A. L. M. S.; MELLO, S. C. B. Validade e confiabilidade na pesquisa qualitativa em Administração. Revista de Ciências da Administração, v. 13, n. 31, p. 190-209, 2011.

PELKA, B.; TERSTRIEP, J. Mapping Social Innovation Maps: the State of Research Practice across Europe. European Public \& Social Innovation Review, San Sebastián, v. 1, n. 1, p. 3-16, 2016.

PHILLIPS, W. et al. Social Innovation and Social Entrepreneurship: a Systematic Review. Group \& Organization Management, v. 40, n. 3, p. 428-461, 2015.

POL, E.; VILLE, S. Social innovation: Buzz word or enduring term? The Journal of Socio-Economics, v. 38, n. 6, p. 878-885, 2009.

SCHATZKI, T. R. Introduction: Practice Theory. In: SCHATZKI, T. R.; CETINA, K. K.; SAVIGNY, E. V. (Ed.). The Practice Turn In Contemporary Theory. London: Routledge, 2001, p. 10-23.

SILVA, S. B.; BITENCOURT, C. C. Rumo a um Quadro Conceitual para o Estudo de "Redes de Inovação Social". In: ENCONTRO DE ESTUDOS ORGANIZACIONAIS, 9., 2016, Belo Horizonte. Anais... Belo Horizonte: ANPAD, 2016. 
SILVEIRA, F. F.; ZILBER, S. N. Is social innovation about innovation? $A$ bibliometric study identifying the main authors, citations and co-citations over 20 years. International Journal of Entrepreneurship and Innovation Management, v. 21, n. 6, p. 459-484, 2017.

TANIMOTO, K. The emergent process of social innovation: multistakeholders perspective. International Journal of Innovation and Regional Development, v. 4, n. 3-4, p. 267-280, 2012.

TEN HAVE, P. Understanding Qualitative Research and Ethnomethodology. London: Sage, 2004.
TRANFIELD, D.; DENYER, D.; SMART, P. Towards a methodology for developing evidence informed management knowledge by means of systematic review. British Journal of Management, v. 14, n. 3, p. 207-222, 2003.

UNPD. Human Development Report. 2016. Available at: <https:// goo.gl/b7WR73>. Accessed on: Aug. 01, 2017.

VAN DER HAVE, R. P.; RUBALCABA, L. Social innovation research: an emerging area of innovation studies? Research Policy, v. 45, n. 9 , p. 1923-1935, 2016.

Thaís Teles Firmino

ORCID: https://orcid.org/0000-0002-3448-1282

Doctoral student in Business Administration from Potiguar University (UnP); Master's in Business Administration from the Federal University of Paraíba (UFPB); Substitute Professor in Department of Business Administration from the Federal University of Paraíba (UFPB), João Pessoa - PB, Brazil. E-mail: thaistfirmino@gmail.com

André Gustavo Carvalho Machado

ORCID: https://orcid.org/0000-0002-0589-896X

Doctor in Business Administration at Federal University of Pernambuco (UFPE); Associate Professor at the Federal University of Paraíba (UFPB), where he teaches undergraduate and graduate courses in Business Administration and Professional Master's courses in Management in Learning Organizations, João Pessoa - PB, Brazil. E-mail: agcmachado@gmail.com 